\title{
"REFLECTIONS OF A SAINT"
}

\author{
By PHILOMUSE
}

IN 1772 the Boston printer John Kneeland published a thin pamphlet containing a poem entitled REFLECTIONS OF A SAINT, UNDER A VIEW OF THE PRESENCE OF AN INFINITELY HOLY AND ALL-SEEING GOD by someone who! signed himself "Philomuse." The only known copy of this eight-page imprint is in the Rutgers Library, though the John Carter Brown Library owns a "mutilated" and undated copy of another printing of the poem in Norwich, Connecticut, by Green and Spooner, printers of that town from 1773 to 1778 . So far no evidence has come to light as to the identity of the author. An examination of the poem leads one to believe that he was probably a New England clergyman who was familiar with the English poetry of the seventeenth century, particularly with that of Milton. In any case he had an unusual poetic gift. For this reason, and because all of our Colonial poetry ought to be preserved and made an accessible part of our heritage, we are reprinting the poem here.

\section{I.}

My great Creator, sovereign LORD,

Form'd and upholds me by his Word.

He Show'rs, the Blassings I possess,

Blessings my Tongue can ne'er express.

A GOD of Mercy, Judge severe

Of every Traspass acted here:

Naked to whose omniscient Eye,

My Thoughts, and Words, and Actions lie.

\section{II.}

His Law (how holy just and pure!)

Shall to Eternity endure;

Strict and extensive it's Command, That claims Perfection at my Hand;

Hears no Excuse by Sin design'd:

Then let me ever bear in mind,

That Thoughts, and Words, and Actions lie

Spread to Jehovah's jealous Eye. 
REFIECTIONS

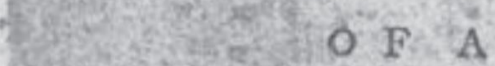

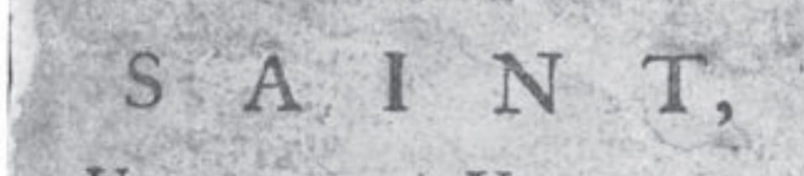

UNDER A VIEW OF

\section{the Presence}

OF A N I

INFINITELY HOLY

A N D

AlL-SeEING GOD.

\section{By PHILOMUSE.}

$$
\text { B } O S \text { T } O N \text { : }
$$

Printed and Sold by J KNEELAND, in Milk-Strect.

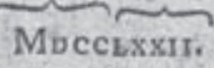


III.

When Morning smiles and I awake, Spring forth my Soul, a Visit make,

To the great Author of the Day;

To him thine early Homage pay.

May he a filial Love impart,

And write with Diamond on my Heart,

"Each Thought, each Word, and Motion lies

"All spread before JEHOVAH'S Eyes."

IV.

Heav'n calls to Action, I'll pursue

What Heart, or Hands, or Tongue can do,

With all my Might, for GOD alone,

Nor feel my Strength or Self my own.

And be the awful Thought impress'd,

Each Moment recent on my Breast,

That Thoughts, and Words, and Actions lie

All naked to my Sovereign's Eye.

V.

When HEAVEN shall give me leave to spend

A social Minute, with my Friend;

Be it the Pleasure of my Heart,

To gain some good, or some impart;

And may we both conspire to give

The Hour to Him by whom we live:

Remembering still our Spirits lie

Expanded to Jehovah's Eye.

VI.

If call'd, to spend an Hour among

A more retir'd, or publick Throng;

Let me with double Guard defend

My Heart, my Eye, my Tongue, and Hand.

By Snares, and Pits of Sin beset,

$\mathrm{O}$ ! let me never more forget

That every Thought in Embryo lies

Plain to my Sovereign's dreadful Eyes. 


\section{VII.}

When Friends the chearful Circle form, Let Virtue ev'ry Bosom warm; Let Virtue ev'ry Thought inspire, And ev'ry Word, fan Virtue's Fire. Let ev'ry Heart with Rev'rence wear The Thought, that GOD Almighty's there; That all our Souls expanded lie Full naked to his piercing Eye.

\section{VIII.}

I'd see my Table spread by GOD, From Him receive my daily Food, Or rather seated at his $\mathrm{B}[\mathrm{o}]$ ard, I'd own the Master, and my LORD: Cautious I'd taste the furnish'd Fare, Full conscious, all the GOD was there; That Thoughts, and Words and Actions lie Exposed to his full jealous Eye.

IX.

I'd read and meditate his LAW And GOSPEL, with an holy Awe; And hear in both my GOD proclaim My Duty, and his wondrous Name: Seize on whate'er I there behold, And prize each Sentence more than Gold; Remembring still, my Thoughts all lie Before JEHOVAH's faming Eye.

$\mathrm{X}$.

In Prayer, my Soul inflam'd with Zeal, And Love, as pure as Angels feel, Should panting, wrestle with my GOD, And plead alone my SAVIOUR's BLOOD: "Thy Kingdom come, thy Will be done, "On Earth as 'tis beyond the Sun; "Write on my Heart that all Things lie "Full naked to thy flaming Eye. 
XI.

"Grant all Mankind the good they need; "The naked cloath; the Hungry feed. "May this my Lot forever be, "My GOD, to love and honour thee: "Compleatly to thy Will resign'd, "May I serene Contentment find: "And joy to think that nought can fly "The Ken of thine all searching Eye."

XII.

At Night I'd lay me down to rest; My soul reclin'd on Jesus' Breast; Review the Business of the Day,See where my Thoughts have gone astray:Condemn myself down to the Deep; Fly to my GOD, and sink to Sleep, Reflecting still, I safely lie Beneath JE $[H] O V A H^{\prime} s^{1}$ guardian Eye.

\section{XIII.}

Thus while my Time whirls swift, away, I'd seize the present, flying Day.

To Heaven each shooting Hour should bear It's load of Duty clad in Prayer. All Men should see, and catch the Flame Of Love to GOD, or shrink with Shame. Oh! may they know their Thoughts all lie, Conspicuous to th' Eternal Eye.

\section{XIV.}

But Oh! the bless'd, the wish'd for Day, When JESUS reassum'd his Clay! Then let my Heart, Soul, Passions rise, And wing their Way above the Skies! Then be my Spirit rap't above, All but the highest Heavens, in Love. There joyful bask beneath the Eye, To which my Thoughts all naked lie.

${ }^{1}$ Misspelled JEAOVAH's. 
XV.

Soon as the Sun with chearful ray,

Should usher in that joyful Day;

Each Heart beneath my Roof should join,

With Voices tun'd to Songs divine,

And welcome in the Day of Rest,

The Day my Soul esteems the best;

And meet with Joy his jealous Eyes,

To whom all Nature naked lies.

\section{XVI.}

When to the Closet I retreat, My own Existence I'd forget; And as the Drops of falling Rain, Sink to Oblivion in the main:

So be my Soul immersed quite, In GOD, the Ocean of Delight; And raptur'd see that all Things lie, Plain to my GOD's unerring Eye.

\section{XVII.}

And at th' appointed Hour, I'll go To worship with the Saints below; Call on the Name of GOD, and sing Hosannahs to th' eternal King: Dwell on his Word with Joy, and Fear, And see his awful Beauty there: Rejoice to think that all Things lie, Spread naked to his flaming Eye.

\section{XVIII.}

But oh! my Heart, how prone to rove, Or fix on some terrest[r]ial Love! How prone to leave the peaceful Road, That leads from Earth to Heav'n and GOD! How prone to gratify the Thirst, And feed the flame of worldly Lust! How thoughtless that all Nature lies, Full spread before Jehovah's Eyes! 
XIX.

And oh, how empty, light and vain, The Thoughts that flutter through my Brain!

How deaf mine Ear to Wisdom's Cry!

To heavenly Charms, how blind my Eye!

How cold my Gratitude, while GOD

For Sinners stains the Cross with Blood!

How thoughtless while his flaming Eye,

Does all my Wickedness descry!

\section{XX.}

My GOD, my King, my Saviour, come, Save me from Sin, or call me home.

$O$ never, never, let me bring

Dishonour, on my GOD and King.

Nor let me waste my future Days,

In Sin's destructive, odious Ways:

Nor e'er forget that all things lie

Full open to thine awful Eye. 